Research Article

Yüksel Gezgin*, Derya Maral Gül, Seçil Sözer Şenşatar, Can Uraz Kara, Sayit Sargın, Fazilet Vardar Sukan and Rengin Eltem

\title{
Evaluation of Trichoderma atroviride and Trichoderma citrinoviride growth profiles and their potentials as biocontrol agent and biofertilizer Trichoderma atroviride ve Trichoderma citrinoviride'nin büyüme profilleri ve biyogübre ile biokontrol ajanı olarak potansiyellerinin değerlendirilmesi
}

https://doi.org/10.1515/tjb-2018-0378

Received September 10, 2018; accepted January 29, 2019

\section{Abstract}

Background: Two Trichoderma species (T. atroviride and T. citrinoviride) were evaluated for their potential to have Trichoderma-based biological control agent and biofertilizer properties.

Materials and Methods: Eight Trichoderma spp. were identified by molecular methods. The mycoparasitic activities against different phytopathogenic fungi and their capacity to produce extracellular lytic enzymes were investigated. Furthermore, indole-3-acetic acid production and phosphate solubilization capabilities of Trichoderma spp. were evaluated together with the effect of some physical parameters and different carbon:nitrogen sources on mycelial growth and conidium production.

Results and Discussion: All strains exhibited lytic enzymes and indole-3 acetic acid production as well as phosphate solubility characteristics. Trichoderma citrinoviride demostrated more mycoparasitic activity against Fusarium oxysporium than T. atroviride whereas T. atroviride was found more effective against Rhizoctonia solani. In particular, at lower temperatures, conidium production of $T$. atroviride strains were significantly higher than $T$. citrinoviride strains. Both strains grew well on all carbon sources

\footnotetext{
*Corresponding author: Yüksel Gezgin, Department of Bioengineering, Faculty of Engineering, Ege University, 35100 Bornova-Izmir, Turkey, Phone: +90 232 3115811; Fax: +90 23231158 80, e-mail: yukselgezgin@gmail.com. https://orcid.org/0000-0001-5812-1882

Derya Maral Gül, Seçil Sözer Şenşatar, Can Uraz Kara, Sayit Sargın, Fazilet Vardar Sukan and Rengin Eltem: Department of Bioengineering, Faculty of Engineering, Ege University, Bornova-Izmir, Turkey
}

tested. The effect of organic nitrogen sources on growth were notably higher than inorganic nitrogen sources. Conclusion: The results provided valuable insight in both the highest mycelial growth and conidia production conditions of these cultures for further similar studies related to development of Trichoderma-based new commercial biological control and biofertilizer formulations in different agro-climatic regions.

Keywords: T. atroviride; T. citrinoviride; biological control agent; biofertilizer; plant growth-promoting fungi.

\section{Öz}

Amaç: İki Trichoderma (T. atroviride ve T. citrinoviride) türününTrichoderma-tabanlı biyolojik kontrol ajanı potansiyelleri ve biyogübre özellikleri değerlendirilmiştir. Gereç ve Yöntemler: Sekiz adet Trichoderma spp. moleküler metotlar kullanılarak tanılanmıştır. Farklı fitopatojenik mantarlara karşı mikoparazitik aktiviteleri ve ekstraselüler litik enzimleri üretme potansiyelleri incelenmiştir. Bunun yanısıra Trichoderma spp. lerinin indol asetik asit üretimi ve fosfat çözünürleştirme kapasiteleri misel büyümesi ve konidiumüretimiüzerine farklı karbon:azot kaynaklarının ve bazı fiziksel parametrelerin etkisi ile birlikte değerlendirilmiştir.

Bulgular ve Tartışma: Tüm suşlar litik enzim, indol asetik asit üretimi ve fosfat çözündürme özellikleri sergilemişlerdir. Trichoderma citrinoviride suşları Fusarium oxysporium'e karşı T. atroviride'den daha fazla mikoparazitik aktivite göstermiştir oysa T. atroviride suşlarının Rhizoctonia solani’ye karşı daha etkili olduğu görülmüştür. Özellikle düşük sıcaklıklarda T. atroviride suşlarının konidium üretimleri T. citrinoviride suşlarına göre daha yüksektir. Her iki suş da test edilen tüm karbon kaynaklarında büyümüştür. Büyüme üzerine organik nitrojen kaynakları inorganik nitrojen kaynaklarına göre yüksektir. 
Sonuç: Sonuçlar farklı iklim bölgelerinde Trichodermatemelli yeni ticari biyolojik kontrol ve biyogübre formülasyonlarının geliştirilmesiyle ilgili benzer çalışmalar için bu kültürlerin hem en yüksek misel büyümesi ve hem konidium üretimleriyle ilgili değerli bilgiler sağlamaktadır.

Anahtar Kelimeler: T. atroviride; T. citrinoviride; biyolojikkontrolajanı; biyogübre; bitki büyümesini teşvik eden mantarlar.

\section{Introduction}

Trichoderma spp. have been studied extensively with respect to many characteristics and are known as successful habitats of the soil ecosystem competing against other fungi [1-4]. Biocontrol process may be performed as indirectly (i.e.: by competition for nutrients and space, chancing the environmental conditions, or promoting plant growth and plant defense mechanisms and antibiosis) or direct mechanisms, as in mycoparasitism [1]. Trichoderma spp. demonstrate considerable mycoparasitic activity due to the production of lytic enzymes such as chitinases, $\beta-1,3-$ glucanases and various proteases $[5,6]$. The production of several antibiotics by Trichoderma spp. helps to improve the plant immune system thereby preventing possible plant infections. Compared to bacterial biological control agents (BCAs), fungal based BCAs exhibit a broader spectrum of activity in terms of disease management and therefore they have gained wide acceptance in the recent years [7-9]. Trichoderma spp. have an important potential as plant growth promoting fungi [6], comprising of almost $50 \%$ of the fungal BCAs market, mostly as plant growth enhancers [7]. Trichoderma spp. have the ability to solubilise valuable nutrients such as phosphate compounds by secreting different organic acids. They also produce different hydrolytic enzymes, contributing to the enrichment of the soil composition. Trichoderma spp. are also effective bioremediation agents due to their ability to degrade xenobiotics, removing potential hazards from the soil. Besides their plant growth enhancement properties, Trichoderma spp. are important candidates for use as BCAs [4].

Some fungal genera such as Trichoderma, Aspergillus, Fusarium, Penicillium are most frequently reported plant growth-promoting (PG-P) fungi and owing to their multiple beneficial effects on plant quantity and quality have attracted considerable interest as bio-fertilisers [10].

Trichoderma-based commercial biofertilizers ( $T$-bcb) have been widely studied for plant growth and plant diseases control [5]. There are many $T$-bcb available in the market such as Bioorganic Plus (NovaScience Co. Ltd,
Thailand), BioVam (T\&J Enterprises, USA), PLantmate ${ }^{\circledR}$ (Agrimms Technologies Ltd), Superzyme (JH Biotech, Inc., Ventura, CA. USA), Tricho ${ }^{\circledR}$ (Agrimms Technologies Ltd) [11].

In this study, eight Trichoderma spp. isolates were evaluated in respect of their potential as BCAs and biofertilizer. The mycoparasitic activity, lytic enzyme productions indole-3-acetic acid (IAA) production and phosphate solubilization (P-S) capabilities of the species were tested together with the effects of temperature in light/dark, different carbon and nitrogen sources on mycelial growth and conidia production (M-G and C-P).

\section{Materials and methods}

\section{Fungal isolates}

Eight Trichoderma spp. (EGE-K-65, 71, 67, 72, 128, 129, 130, 131) were isolated from lumbering industry in Turkey.

For the isolation of Trichoderma spp., the soil dilution plating method was used [2]. The diluted samples were directly plated onto Rose Bengal Chloramphenicol agar as a selective medium. After 6 days of incubation at $28^{\circ} \mathrm{C}$, fungal colonies were transferred to Malt Extract Agar (MEA) slants and they were stored $+4^{\circ} \mathrm{C}$ for further investigations.

\section{Determining the optimal medium for Trichoderma spp.}

Five different growth media were used for evaluation of M-G and C-P at $28^{\circ} \mathrm{C}$ for 6 days. Tested growth media were as follows; Malt Yeast Glucose agar (MYGA) medium, MEA, Czapek Dox Agar (CDA), Modified CDA and Mendel's Medium [7, 12]. Since optimum $\mathrm{pH}$ values for the growth of the isolates were found as between $\mathrm{pH} 5.0$ and 6.0 previously [13], it was kept constant at pH 5.50 in further experiments performed in this study.

\section{DNA extraction, PCR amplifications and sequencing}

For DNA extraction, fungal isolates were cultivated on MYGA at $28^{\circ} \mathrm{C}$ for 6 days. DNA extraction was carried out as described previously by Chen et al. [14]. The ITS region of the nuclear rDNA gene cluster was amplified from DNA using primers ITS1 (TCCGTAGGTGAACCTGCGG) and ITS4 
(TCCTCCGCTTATTGATATGC) [15]. PCR amplifications and sequencing were performed by REFGEN (Turkey). The sequences were aligned in Molecular Evolutionary Genetics Analysis (MEGA) v.6 using Clustal W. The Phylogenetic trees were established with Maximum Likelihood method in MEGA v.6. For determining each clade, a bootstrap analysis was performed with 1000 replication.

\section{Screening of Trichoderma spp. as a BCAs in vitro}

\section{Analysis of mycoparasitic activity against some phytopathogenic fungi in vitro}

Three phytopathogenic fungi (Verticillium sp., R. solani and $F$. oxysporium) were obtained from the culture collection of Ege University Department of Plant Protection. The mycoparasitic activities of Trichoderma spp. were tested by dual culture techniques against phytopathogenic fungi after co-cultivation on PDA at $28^{\circ} \mathrm{C}$ for 10 days. Antagonism was also carried out according to the classification proposed by Bell et al. [2, 16, 17].

\section{Determination of lytic enzyme activities}

$\beta-1.3$ Glucanase activity (EC 3.2.1.39), chitinase activity (EC 3.2.1.14) and protease activity (EC3.4.21.4) were determined $[18,19]$ by using modified Trichoderma Liquid Enzyme (TLE) [20]. The components of the medium used for lytic enzyme production were as follows: $0.1 \%$ bactopeptone, $1.43 \%$ corn steep solids (CSS), $\mathrm{KH}_{2} \mathrm{PO}_{4} 0.2 \%$, $0.03 \% \mathrm{MgSO}_{4} \cdot 7 \mathrm{H}_{2} \mathrm{O}, 0.03 \%$ glucose, and $0.1 \%(\mathrm{v} / \mathrm{v})$ trace elements solution containing $\mathrm{Fe}^{2+}, \mathrm{Zn}^{2+}, \mathrm{Mn}^{2+}, \mathrm{Cu}^{2+}[20]$.

This medium (50 mL), in $250 \mathrm{~mL}$ flask, was inoculated with $1.0 \times 10^{8}$ (microscopic count) spores of Trichoderma spp., and incubated on rotary shaker $(180 \mathrm{rpm})$ at $27^{\circ} \mathrm{C}$ and $30^{\circ} \mathrm{C}$, respectively, for 4 and 7 days. Supernatant was separated and stocked at $-20^{\circ} \mathrm{C}$ until enzyme activity measurement. All experiments were performed in duplicate.

\section{Analysis of $\beta-1,3$-glucanase activity}

$\beta$-1, 3-glucanase activity (EC 3.2.1.39) was measured using $25 \%(\mathrm{w} / \mathrm{v})$ suspension of laminarin that dissolved in $50 \mathrm{mM}$ acetate buffer ( $\mathrm{pH}$ 5.0) at $40^{\circ} \mathrm{C}$ for $30 \mathrm{~min}$. Reducing sugars liberated from the substrate were determined with dinitrosalicylic acid (DNS) method described by Miller [18]. One unit of $\beta-1,3$-glucanase activity was defined as the amount of enzyme that released $1 \mu \mathrm{mol}$ reducing sugar in 1 min under assay conditions.

\section{Determination of chitinase activity}

Chitin (0.5\%) obtained from crab shells (Sigma C7170) was used as substrate in modified TLE medium for chitinase activity. Chitinase activity was measured in terms of the amount of N-acetyl-D-glucosamine sugars released from chitin. Reducing sugars liberated from the substrate were determined with DNS method described by Miller [18]. One unit (U) of chitinase activity was defined as the amount of enzyme necessary to produce $1 \mu \mathrm{mol}$ of $N$-acetylglucosamine (NAG) in $1 \mathrm{~min}[18]$.

\section{Analysis of protease activity}

Protease activity (EC3.4.21.4) was measured using azocasein (Sigma, A2765) as the substrate as described by Chun et al. [19]. One unit (U) protease activity was defined as the amount necessary to increase the absorbance at the rate of 0.01 at $440 \mathrm{~nm}$ in $1 \mathrm{~min}$ [19].

\section{Screening of Trichoderma spp. as biofertilizers in vitro}

\section{Analysis of IAA production by Trichoderma spp.}

Flasks $(250 \mathrm{~mL})$ containing $50 \mathrm{~mL}$ of half-strength Tryptic Soy Broth (TSB, Sigma-Aldrich) supplemented with $200 \mu \mathrm{g} / \mathrm{mL}$ L-tryptophan (Fluka, 22092) were inoculated with three agar plugs of $6 \mathrm{~mm}$ from 6 days old Trichoderma spp. and the flasks were incubated at $27^{\circ} \mathrm{C}$ at $150 \mathrm{rpm}$ [21]. After 7 days of incubation, the cultures were filtered. IAA $(\mathrm{mg} / \mathrm{L})$ was measured by mixing $1 \mathrm{~mL}$ of the filtrate with $2 \mathrm{~mL}$ of Salkowski reagent $\left(150 \mathrm{~mL}\right.$ of $\mathrm{HClO}_{4}, 250 \mathrm{~mL}$ of distilled water and $7.5 \mathrm{~mL}$ of $0.5 \mathrm{M} \mathrm{FeCl}_{3} \cdot 6 \mathrm{H}_{2} \mathrm{O}$ ) [21]. Reaction mixtures were incubated at room temperature for $20 \mathrm{~min}$ and the absorbances were measured at $535 \mathrm{~nm}$ [21].

\section{Analysis of P-S capacity of Trichoderma spp.}

P-S was determined using the method previously described by Murphy and Riley [22]. The $250 \mathrm{~mL}$ flasks containing 50 mL National Botanical Research Institute's Phosphate growth medium (NBRIP) were inoculated with $1.0 \times 10^{8}$ spores per $\mathrm{mL}$. 
The medium contained $\mathrm{L}^{-1}$ : glucose, $10 \mathrm{~g}, \mathrm{Ca}_{3}\left(\mathrm{PO}_{4}\right)_{2}$, $5 \mathrm{~g}, \mathrm{MgCl}_{2} \cdot 6 \mathrm{H}_{2} \mathrm{O}, 5 \mathrm{~g}, \mathrm{MgSO}_{4} \cdot 7 \mathrm{H}_{2} \mathrm{O}, 0.25 \mathrm{~g}, \mathrm{KCl}, 0.2 \mathrm{~g}$ and $\left(\mathrm{NH}_{4}\right)_{2} \mathrm{SO}_{4}, 0.1 \mathrm{~g}$ [23]. All flasks were incubated for 10 days at $27^{\circ} \mathrm{C}, 150 \mathrm{rpm}$. After incubation, cultures were filtrated and P-S (mg/L) was measured by mixing $40 \mathrm{~mL}$ of the filtrate with $8 \mathrm{~mL}$ of ascorbic acid solution. Reaction mixtures were allowed to stay at room temperature for $10 \mathrm{~min}$ and the absorbances were measured at $700 \mathrm{~nm}$.

\section{Effect of temperature, carbon and nitrogen sources on M-G and C-P}

Highest M-G and C-P at different conditions were evaluated, including different incubation temperature in light and dark conditions, the use of different carbon and nitrogen sources [12, 24-26].

The growth of each strain was measured by colony diameter [17]. The conidia production of Trichoderma spp. was graded as $(-), 1(+), 2(+), 3(+), 4(+), 5(+)$.

\section{Analysis of different temperatures in light and dark conditions}

The effect of different temperatures on M-G and C-P under light (130 lux) [27] and dark conditions were investigated using 12 different temperatures $(4,10,15,20,24$, $27,30,33,35,40,43$ and $\left.45^{\circ} \mathrm{C}\right)$. An agar plug of $6 \mathrm{~mm}$, from 6 days old Trichoderma spp. was centrally inoculated on MYGA and the plates were incubated at temperatures listed above.

\section{Effect of different carbon sources on growth}

Sixteen different carbon sources (glucose, fructose, galactose, maltose, saccharose, lactose, raffinose, arabinose, cellulose, chitin, glycerol, mannitol, sorbitol, xylitol, trehalose and xylose) were used to determine their effect on growth. Each carbon source at a final concentration of $1 \%$ (w/v) was added into MCMA (carbon source, $10.0 \mathrm{~g} / \mathrm{L}$; yeast extract, $7.0 \mathrm{~g} / \mathrm{L} ; \mathrm{NaNO}_{3}, 2 \mathrm{~g} / \mathrm{L} ; \mathrm{KCl}, 0.5 \mathrm{~g} / \mathrm{L} ; \mathrm{MgSO}_{4}$, $0.5 \mathrm{~g} / \mathrm{L} ; \mathrm{FeSO}_{4}, 0.01 ; \mathrm{K}_{2} \mathrm{HPO}_{4}, 1.0 \mathrm{~g} / \mathrm{L}$; agar, $\left.20.0 \mathrm{~g} / \mathrm{L}\right)[12]$ and all plates were incubated at $28^{\circ} \mathrm{C}$ for 3 days.

\section{Effect of different nitrogen sources on growth}

Eight different nitrogen sources (yeast extract, corn steep solid, soybean flour, peptone, urea, sodium nitrate, ammonium sulfate and diammonium hydrogen phosphate) were used to test their effect on growth. Each nitrogen source at a final concentration of $0.7 \%(\mathrm{w} / \mathrm{v})$ was added into MCMA (nitrogen source, $7.0 \mathrm{~g} / \mathrm{L}$; glucose, 10.0 $\mathrm{g} / \mathrm{L} ; \mathrm{NaNO}_{3}, 2 \mathrm{~g} / \mathrm{L} ; \mathrm{KCl}, 0.5 \mathrm{~g} / \mathrm{L} ; \mathrm{MgSO}_{4}, 0.5 \mathrm{~g} / \mathrm{L} ; \mathrm{FeSO}_{4}$, $0.01 ; \mathrm{K}_{2} \mathrm{HPO}_{4}, 1.0 \mathrm{~g} / \mathrm{L}$; agar, $20 \mathrm{~g} / \mathrm{L}$ ) [12]. All plates were incubated at $28^{\circ} \mathrm{C}$ for 3 days.

\section{Statistical analysis}

The experiments were carried out in triplicate. The results were statistically analyzed and Tukey test was used to compare the differences and to determine the standard deviations and standard errors of the means and to test the significance of treatment at $\mathrm{p} \leq 0.05$.

\section{Results and discussion}

\section{Determination of the optimal medium for Trichoderma spp.}

Among the tested media, MYGA was determined as a optimal medium for the cultivation of Trichoderma spp. after observational comparison (data not shown) [7]. Further studies were carried out by using MYGA.

\section{Identification of Trichoderma strains by molecular methods}

The ITS rDNA region of Trichoderma spp. was sequenced and the fungal isolates were identified as $T$. atroviride $(\mathrm{n}=3)$, T. citrinoviride $(\mathrm{n}=5)$. The GenBank accession numbers are shown on Table 1 and the phylogenetic trees were constructed with MEGA v.6 as seen on Figure 1.

\section{Screening of Trichoderma spp. as a BCAs in vitro}

Analysis of mycoparasitic activity of Trichoderma spp. against some phytopathogenic fungi in vitro

Trichoderma spp. vary considerably in their mycoparazitic activity against phytopathogenic fungi $[8,28]$. For instance, it has been reported that $T$. atroviride caused significant decrease in growth rate of Leptosphaeria spp. [3], and $R$. solani $[8,28]$. 
Table 1: Genbank accession numbers of DNA sequences, Length of Sequence (bp), isolation source of Trichoderma spp. used in phylogenetic analyses, $T$. atroviride $(\mathrm{n}=3)$ and $T$. citrinoviride $(\mathrm{n}=5)$.

\begin{tabular}{|c|c|c|c|c|c|}
\hline Trichoderma spp. & Isolates names & Length of sequence (bp) & Genbank accession number & Isolation source & Country of origin \\
\hline T. atroviride & EGE-K-65 & 588 & JX119037 & Lumber & Turkey \\
\hline T. atroviride & EGE-K-71 & 598 & JX119036 & Lumber & Turkey \\
\hline T. atroviride & EGE-K-131 & 712 & JX119035 & Lumber & Turkey \\
\hline T. citrinoviride & EGE-K-67 & 799 & $J X 125613$ & Lumber & Turkey \\
\hline T. citrinoviride & EGE-K-72 & 639 & $J X 125614$ & Lumber & Turkey \\
\hline T. citrinoviride & EGE-K-128 & 823 & JX125615 & Lumber & Turkey \\
\hline T. citrinoviride & EGE-K-129 & 818 & JX125616 & Lumber & Turkey \\
\hline T. citrinoviride & EGE-K-130 & 597 & JX125617 & Lumber & Turkey \\
\hline
\end{tabular}

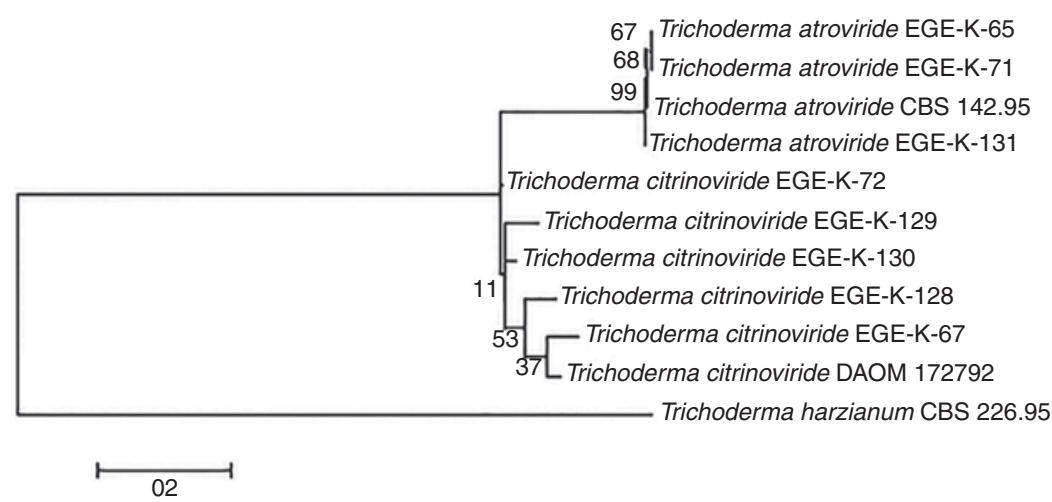

Figure 1: The phylogenetic tree for T. citrinoviride and T. atroviride and relative species based on the internal transcribed spacer (ITS) ribosomal DNA (rDNA) gene sequences.

In this study, all of the Trichoderma spp. overgrew on the mycelia of Verticillium sp. Interestingly, T. citrinoviride demostrated strong effect against $F$. oxysporium and $T$. atroviride was very effective against $R$. solani. This is particularly important to improve the antagonistic effects of BCAs on phytopathogenic fungi and particularly important for the biocontrol of phytopathogenic fungi such as $F$. oxysporium and $R$. solani [1].

Mycoparasitism also involves some morphological changes [9]. As seen on Figure 2, significant antagonist action leading to morphological changes in vitro was achieved by $T$. citrinoviride (EGE-K-72 and EGE-K-128) against F. oxysporium.

\section{Lytic enzyme activities}

Chitinase, protease and $\beta$-1,3-glucanase are known as mycoparasitism-related enzymes (Table 2), since they are degrading the cell wall and inhibiting the growth of phytopathogenic fungi. Furthermore, $\beta$-1,3-glucanase inhibits spore germination of phytopathogen together with chitinases [1]. In the present study, all Trichoderma spp. produced lytic enzymes such as chitinase, protease and $\beta$-1,3-glucanase. The chitinase, 1,3-glucanase and protease activities for T. citrinoviride and T. atroviride species were determined as $0.17-0.21$ and $0.14-0.17 \mathrm{U} / \mathrm{mL}, 0.12$ 0.21 and $0.07-0.25$ at $\mathrm{U} / \mathrm{mL}$ and, $0.64-2.29$ and $1.76-1.22 \mathrm{U} /$ $\mathrm{mL}$, respectively (Table 2).

\section{Screening of Trichoderma spp. in respect of biofertilizer properties in vitro}

\section{Analysis of IAA production by Trichoderma spp.}

Several Trichoderma species can produce PG-P substances such as the auxin phytohormone IAA. Its production has been suggested to promote root growth, and resulting in increased root mass [29].

IAA production levels in this study were determined to be a minimum of $5.65 \pm 0.05$ and $11.56 \pm 1.92 \mathrm{mg} / \mathrm{L}$ and a maximum of $8.81 \pm 0.03$ for $T$. atroviride and $57.01 \pm 3.11 \mathrm{mg} / \mathrm{L}$ for T. citrinoviride (Table 2). 


\begin{tabular}{|c|c|c|c|c|c|c|c|}
\hline \multirow{2}{*}{$\begin{array}{l}\text { Trichoderma } \\
\text { Strains }\end{array}$} & \multicolumn{3}{|c|}{ Phytopathogenic fungi used in this study } & \multirow{2}{*}{$\begin{array}{c}\text { Trichoderma } \\
\text { Strains }\end{array}$} & \multicolumn{3}{|c|}{ Phytopathogenic fungi used in this study } \\
\hline & Verticillium sp., & $\begin{array}{l}\text { Rhizoctonia } \\
\quad \text { solani }\end{array}$ & $\begin{array}{l}\text { Fusarium } \\
\text { oxysporium }\end{array}$ & & Verticillium sp., & $\begin{array}{c}\text { Rhizoctonia } \\
\text { solani }\end{array}$ & $\begin{array}{l}\text { Fusarium } \\
\text { oxysporium }\end{array}$ \\
\hline $\begin{array}{l}\text { Control plate } \\
\text { without } \\
\text { Trichoderma } \\
\text { strains }\end{array}$ & & & & $\begin{array}{c}\text { T. citrinoviride } \\
\text { EGE-K-67 }\end{array}$ & & & \\
\hline $\begin{array}{l}\text { T.atroviride } \\
\text { EGE-K-65 }\end{array}$ & & & & $\begin{array}{l}\text { T. citrinoviride } \\
\text { EGE-K-72 }\end{array}$ & & & \\
\hline $\begin{array}{l}\text { T.atroviride } \\
\text { EGE-K-71 }\end{array}$ & & & & $\begin{array}{l}\text { T. citrinoviride } \\
\text { EGE-K-128 }\end{array}$ & & & \\
\hline $\begin{array}{l}\text { T.atroviride } \\
\text { EGE-K-131 }\end{array}$ & & & & $\begin{array}{l}\text { T. citrinoviride } \\
\text { EGE-K-129 }\end{array}$ & & & \\
\hline & & & & $\begin{array}{l}\text { T. citrinoviride } \\
\text { EGE-K-130 }\end{array}$ & & & \\
\hline
\end{tabular}

Figure 2: Dual growth Trichoderma spp. and three phytopathogenic fungi (Verticillium sp, Rhizoctonia solani and Fusarium oxysporium) at $27^{\circ} \mathrm{C}$ for 10 days.

According to Bell's classification each number represents a different growth pattern as follows: (1) Trichoderma completely overgrew the pathogen and covered the entire medium surface, (2) Trichoderma overgrew at least two-thirds of the medium surface, (3) Trichoderma and the pathogen each colonized approximately one-half of the medium surface and neither organism dominated the other, (4) the pathogen colonized at least two-thirds of the medium surface and withstood encroachment by Trichoderma and (5) the pathogen completely dominated Trichoderma, overgrew it, and occupied the entire medium surface.

Table 2: Lytic enzymes, Indole-3-acetic acid production and phosphate solubilization of $T$. atrorivide and T. citrinoviride species at $27^{\circ} \mathrm{C}$ and $30^{\circ} \mathrm{C}$, respectively.

\begin{tabular}{|c|c|c|c|c|c|c|c|c|c|}
\hline \multirow{3}{*}{$\begin{array}{l}\text { Trichoderma } \\
\text { spp. }\end{array}$} & \multicolumn{7}{|c|}{ Lytic enzymes ${ }^{a}(\mathrm{U} / \mathrm{mL})$} & \multirow{3}{*}{$\begin{array}{r}\text { IAA }^{\mathrm{a}} \\
\text { production } \\
(\mathrm{mg} / \mathrm{L}) \\
7 \text { days }\end{array}$} & \multirow{3}{*}{$\begin{array}{r}\text { Phosphate } \\
\text { solubility }^{\mathrm{a}} \\
(\mathrm{mg} / \mathrm{L}) \\
10 \text { days }\end{array}$} \\
\hline & & \multicolumn{2}{|r|}{ Chitinase } & \multicolumn{2}{|l|}{ Protease } & \multicolumn{2}{|c|}{$\beta$-1,3-Glucanase } & & \\
\hline & & 4 days & 7 days & 4 days & 7 days & 4 days & 7 days & & \\
\hline \multirow{3}{*}{$\begin{array}{l}\text { T. atroviride } \\
(\mathrm{n}=3)\end{array}$} & Min & $0.12 \pm 0.01$ & $0.05 \pm 0.01$ & $0.56 \pm 0.10$ & ND & $0.05 \pm 0.04$ & $0.16 \pm 0.07$ & $5.65 \pm 0.05$ & $2.94 \pm 0.03$ \\
\hline & Max & $0.16 \pm 0.01$ & $0.29 \pm 0.03$ & $2.7 \pm 0.10$ & $2.27 \pm 0.93$ & $0.10 \pm 0.01$ & $0.40 \pm 0.27$ & $8.81 \pm 0.03$ & $8.69 \pm 0.04$ \\
\hline & Mean & 0.14 & 0.17 & 1.76 & 1.22 & 0.07 & 0.25 & 7.23 & 6.01 \\
\hline \multirow{3}{*}{$\begin{array}{l}\text { T. citrinoviride } \\
(\mathrm{n}=5)\end{array}$} & Min & $0.06 \pm 0.02$ & $0.19 \pm 0.07$ & $1.13 \pm 0.33$ & ND & $0.05 \pm 0.04$ & ND & $11.56 \pm 1.92$ & $9.07 \pm 0.50$ \\
\hline & $\operatorname{Max}$ & $0.24 \pm 0.08$ & $0.29 \pm 0.02$ & $2.99 \pm 0.82$ & $1.73 \pm 0.73$ & $0.23 \pm 0.02$ & $0.37 \pm 0.07$ & $57.01 \pm 3.11$ & $16.24 \pm 2.73$ \\
\hline & Mean & 0.17 & 0.21 & 2.29 & 0.64 & 0.12 & 0.21 & 23.50 & 12.54 \\
\hline
\end{tabular}

ancubation period is 4-7 days for enzymes, 7 days for IAA production and 10 days for phosphate solubility, ND, Not detected.

\section{Analysis of P-S capacity of Trichoderma spp.}

Trichoderma species are potential phosphate solubilizing microorganisms and play an important role in providing phosphorus to plants [22, 23, 30,31]. Studies related to several Trichoderma-based biofertilizers are available and they are used for controlling plant diseases and promoting plant growth $[10,30]$. Therefore, T. atroviride and T. citrinoviride were screened for in-vitro P-solubilization. The average concentrations of phosphate $(\mathrm{mg} / \mathrm{L})$ were determined as $6.01 \mathrm{mg} / \mathrm{L}$ for T. atroviride and $12.54 \mathrm{mg} / \mathrm{L}$ for T. citrinoviride (Table 2). Although this value is higher 
than that obtained in Gravel et al. [21], there are some reports mentioning much higher amounts of phosphate solubility (up to $404.07 \mu \mathrm{g} \cdot \mathrm{mL}^{-1}$ ) values as compared to this study [30, 31]. Since the main aim was not to optimize phosphate solubilisation, further optimization need to be performed to be able to obtain higher values especially considering the incubation period with time course productions.

\section{Effect of temperature, carbon and nitrogen sources on $\mathbf{M - G}$ and C-P}

\section{Analysis of different temperatures in light and dark conditions}

Studies indicated that there were significant differences on the fungal M-G and C-P due to physical growth conditions such as incubation temperature together with light and dark conditions and nutritional requirements using different carbon and nitrogen sources [9, 24, 32].
The mycelia growth and conidia production of all T. atroviride and T. citrinoviride species in the present study were affected by different temperatures as well as light and dark conditions. The differences are significant $(\mathrm{p}<0.05)$ between T. citrinoviride and T. atroviride species at different temperatures in light/dark conditions.

Optimum growth temperatures were found to be $27^{\circ} \mathrm{C}$ for T. atroviride and between 27 and $35^{\circ} \mathrm{C}$ for T. citrinoviride (Figures 3A,B, Figure 4A,B).

Although strains of all five T. citrinoviride grew well between at $15^{\circ} \mathrm{C}$ and $40^{\circ} \mathrm{C}$, no growth was observed above $40^{\circ} \mathrm{C}$ and below $15^{\circ} \mathrm{C}$ after 3 days of incubation under light conditions (Figure 3A). However, all T. citrinoviride strains were able to grow at $43^{\circ} \mathrm{C}$ for 3 days under dark condition (Figure 3B). Interestingly, T. citrinoviride EGE-KL-128 grew at $10^{\circ} \mathrm{C}$ for 3 days under both light and dark conditions (Figure 3A,B).

Strains of T. atroviride grew well between $15^{\circ} \mathrm{C}$ and $30^{\circ} \mathrm{C}$ after 3 days of incubation under light conditions (Figure $4 \mathrm{~A}$ ) and they were able to grow at $15^{\circ} \mathrm{C}-33^{\circ} \mathrm{C}$ for 3 days under dark conditions (Figure 4B). Previous studies

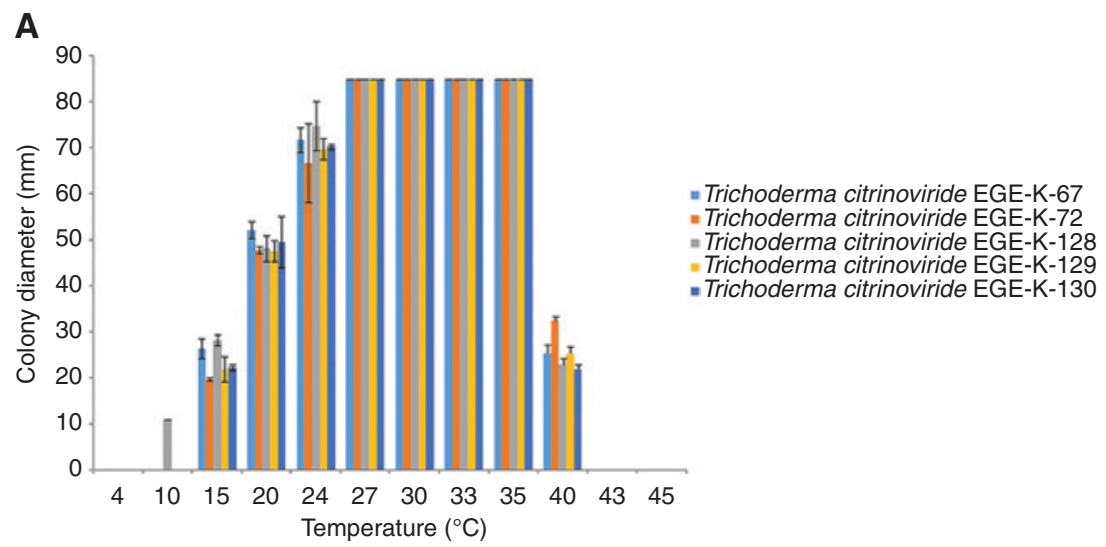

B

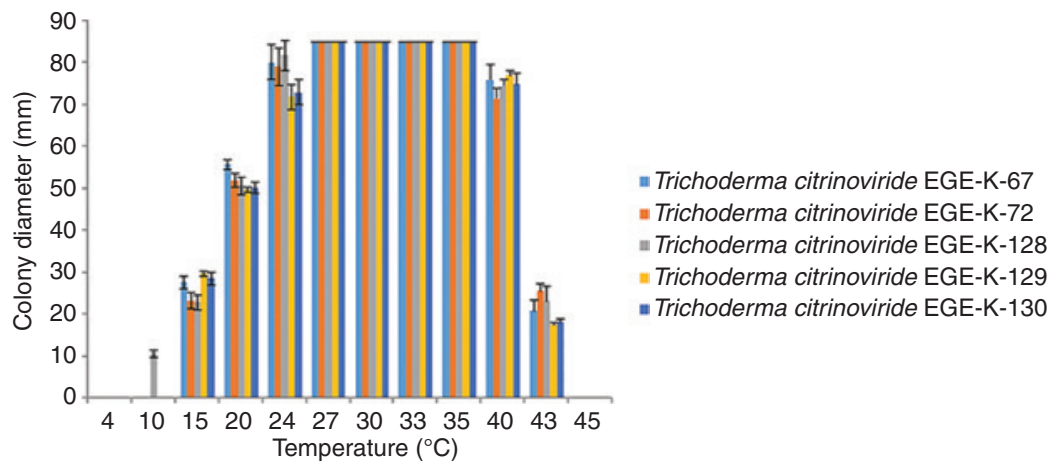

Figure 3: (A) Effect of different temperature (4, 10, 15, 20, 24, 27, 30, 33, 35, 40 and $\left.45^{\circ} \mathrm{C}\right)$ on mycelia growth profiling of $T$. citrinoviride in light (130 lux) for 3 days. (B) Effect of different temperature $\left(4,10,15,20,24,27,30,33,35,40\right.$ and $\left.45^{\circ} \mathrm{C}\right)$ on mycelia growth profiling of T. citrinoviride in dark condition for 3 days.

The differences are significant $(\mathrm{p}<0.05)$ between $T$. citrinoviride and $T$. atroviride species at different temperatures in light. 
A

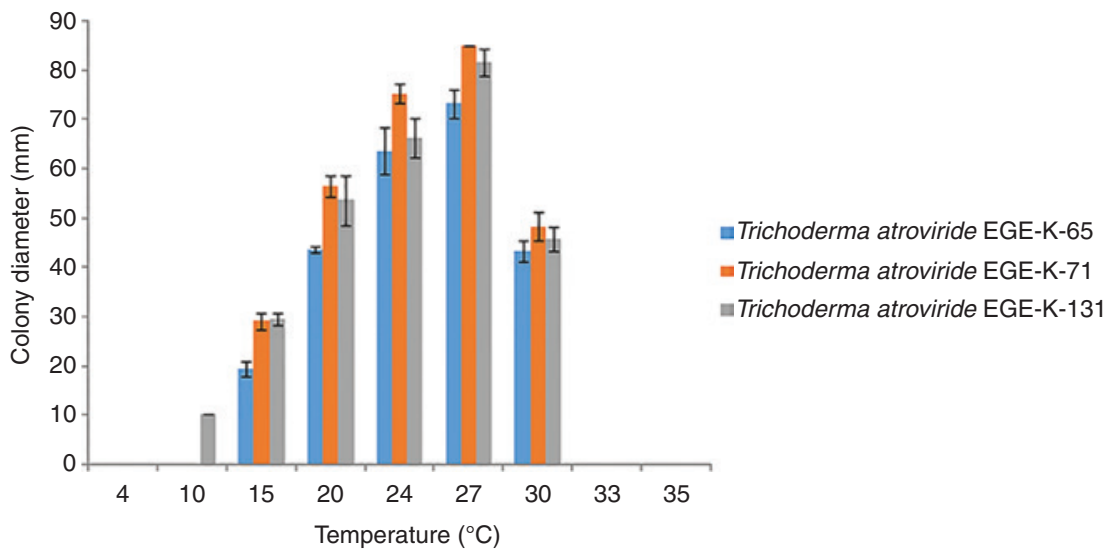

B

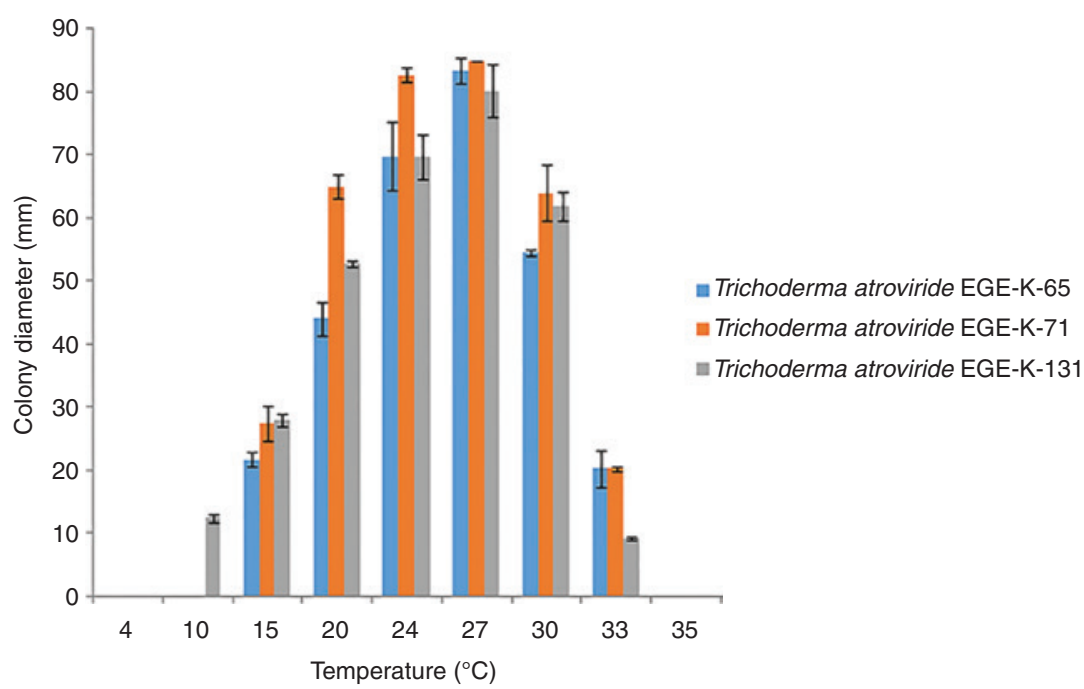

Figure 4: (A) Effect of different temperature $\left(4,10,15,20,24,27,30,33,35,40\right.$ and $\left.45^{\circ} \mathrm{C}\right)$ on mycelia growth profiling of $T$. atroviride in the light (130 lux) condition for 3 days. (B) Effect of different temperature $\left(4,10,15,20,24,27,30,33,35,40\right.$ and $\left.45^{\circ} \mathrm{C}\right)$ mycelia growth profiling of $T$. atroviride in the dark condition for 3 days.

The differences are significant $(\mathrm{p}<0.05)$ between $T$. citrinoviride and T. atroviride species at different temperatures in dark.

by Daryaei et al. [25] have shown that conidia production was enhanced by $T$. atroviride LU132 colonies with the exposure of dark conditions. All strains grew at $10^{\circ} \mathrm{C}$ after 1 week in both light and dark conditions except for T. atroviride EGE-K-131 which grew at $10^{\circ} \mathrm{C}$ for 3 days (Figure 4A,B).

In general, conidia production temperature ranges were determined as $15-30^{\circ} \mathrm{C}$ and $20-35^{\circ} \mathrm{C}$ for T. atroviride and T. citrinoviride (Table 3 ). These results are comparable with the study reported by Daryaei et al. [24] where lower amount of conidia produced at $30^{\circ} \mathrm{C}$. They reported that the best conidia production for T. atroviride was produced at $25^{\circ} \mathrm{C}$.

None of the strains produced conidia at $4^{\circ} \mathrm{C}, 10^{\circ} \mathrm{C}$, $43^{\circ} \mathrm{C}$ and $45^{\circ} \mathrm{C}$ for 10 days in the present study. It is also worth mentioning that, at lower temperatures, conidia production of T. atroviride was significantly higher than T. citrinoviride (Table 3). On the other hand, the highest conidia production for T. citrinoviride was achieved between $33^{\circ} \mathrm{C}$ and $35^{\circ} \mathrm{C}$ and it declined at $40^{\circ} \mathrm{C}$ (Table 3 ).

Overall evaluation of temparature effect on growth suggested that $T$. atroviride produced higher amount of conidia at lower temperatures as compared to T. citrinoviride. Likewise, the conidia production pattern of T. citrinoviride seemed to increase as the temperature increased. Significant differences were found when growing both species at different temperatures under the effect of light and dark. Thus, the highest conidia production perfomances of both Trichoderma species in the wide temperature range provided that it is possible to take this advantage for the production of BCAs in different climatic conditions around the world. 
Table 3: Effect of temperature on conidium production of Trichoderma spp. in dark and light conditions at 10 days.

\begin{tabular}{|c|c|c|c|c|c|c|c|c|c|c|c|c|c|c|c|c|c|}
\hline \multirow[t]{3}{*}{ Trichoderma spp } & \multirow[t]{3}{*}{ Isolate name } & \multicolumn{16}{|c|}{ Temperatures } \\
\hline & & \multicolumn{2}{|r|}{$15^{\circ} \mathrm{C}$} & \multicolumn{2}{|r|}{$20^{\circ} \mathrm{C}$} & \multicolumn{2}{|r|}{$24^{\circ} \mathrm{C}$} & \multicolumn{2}{|r|}{$27^{\circ} \mathrm{C}$} & \multicolumn{2}{|r|}{$30^{\circ} \mathrm{C}$} & \multicolumn{2}{|r|}{$33^{\circ} \mathrm{C}$} & \multicolumn{2}{|r|}{$35^{\circ} \mathrm{C}$} & \multicolumn{2}{|r|}{$40^{\circ}$} \\
\hline & & D & $\mathbf{L}$ & D & $\mathbf{L}$ & D & $\mathbf{L}$ & D & $\mathbf{L}$ & D & $\mathbf{L}$ & D & $\mathbf{L}$ & D & $\mathbf{L}$ & D & \\
\hline \multirow[t]{3}{*}{ T. atroviride } & EGE-K-65 & $4(+)$ & $4(+)$ & $5(+)$ & $5(+)$ & $5(+)$ & $5(+)$ & 4(+) & $5(+)$ & $3(+)$ & $3(+)$ & - & - & - & - & - & \\
\hline & EGE-K-71 & $4(+)$ & $4(+)$ & $5(+)$ & $5(+)$ & $4(+)$ & $5(+)$ & $4(+)$ & $5(+)$ & 4(+) & $5(+)$ & - & - & - & - & - & - \\
\hline & EGE-K-131 & $3(+)$ & $3(+)$ & $5(+)$ & $5(+)$ & $5(+)$ & $5(+)$ & $5(+)$ & $5(+)$ & $5(+)$ & $4(+)$ & - & - & - & - & - & - \\
\hline \multirow[t]{5}{*}{ T.citrinoviride } & EGE-K-67 & $2(+)$ & $4(+)$ & $3(+)$ & $4(+)$ & $3(+)$ & $4(+)$ & $4(+)$ & $4(+)$ & $4(+)$ & $5(+)$ & $5(+)$ & $5(+)$ & $5(+)$ & $5(+)$ & $1(+)$ & $1(+)$ \\
\hline & EGE-K-72 & $2(+)$ & $1(+)$ & 4(+) & $5(+)$ & $4(+)$ & $5(+)$ & 4(+) & $5(+)$ & $5(+)$ & $5(+)$ & $5(+)$ & $5(+)$ & $5(+)$ & $5(+)$ & $1(+)$ & $1(+)$ \\
\hline & EGE-K-128 & $1(+)$ & $2(+)$ & $3(+)$ & $5(+)$ & $4(+)$ & $5(+)$ & $4(+)$ & $4(+)$ & $5(+)$ & $5(+)$ & $5(+)$ & $5(+)$ & $5(+)$ & $5(+)$ & $1(+)$ & $1(+)$ \\
\hline & EGE-K-129 & $1(+)$ & $2(+)$ & 4(+) & $4(+)$ & $4(+)$ & $5(+)$ & 4(+) & $5(+)$ & 4(+) & $5(+)$ & $5(+)$ & $5(+)$ & $5(+)$ & $5(+)$ & $1(+)$ & $1(+)$ \\
\hline & EGE-K-130 & - & $1(+)$ & 4(+) & $5(+)$ & $4(+)$ & $5(+)$ & 4(+) & $5(+)$ & $5(+)$ & $5(+)$ & $5(+)$ & $5(+)$ & $5(+)$ & $5(+)$ & $1(+)$ & $1(+)$ \\
\hline
\end{tabular}

The conidium production of Trichoderma spp. was observed during 10 days and was graded as (-), 1(+), 2(+), 3(+), 4(+), 5(+). D, Dark condition; L, light condition. None of species produced conidia at $4^{\circ} \mathrm{C}, 10^{\circ} \mathrm{C}, 43^{\circ} \mathrm{C}$ and $45^{\circ} \mathrm{C}$ for 10 days.

\section{Effect of different carbon sources on growth}

One of the most important factor that effect production of Trichoderma-based BCAs is the carbon source and several scientists have tried different substrates as a carbon source to obtain high sporulation [33-35].

Both species ( $T$. atroviride and T. citrinoviride) grew well on all carbon sources tested in the present study. No significant differences in mycelial growth were observed with respect to different carbon sources used tested (Figure 5A and B). In a similar study, sucrose, mannose, glucose, xylose, and starch were found effective for the growth of T. harzianum as compared to maltose and D-galactose [33] whereas glucose [36] sucrose [35] and cellobiose [37] were found favourable in other studies.

It is worth mentioning that no conidia production was observed after 10 days of incubation with some carbon sources tested in this study. These carbon sources are maltose, raffinose, cellulose, chitin, sorbitol for T. atroviride EGE-K-65; saccharose, raffinose, cellulose for $T$. citrinoviride EGE-K-72; maltose, saccharose, raffinose, cellulose, chitin, xylitol for T. citrinoviride EGE-K-129; and saccharose, lactose, raffinose, cellulose, chitin, xylitol for T. citrinoviride EGE-K-130 (data not shown).

It has been reported that the Carbon:Nitrogen (C:N) ratios of media had significant effects on the spore yield of fungal BCAs to optimize nutritional conditions for mass production [38]. Daryaei et al. [24] reported that different $\mathrm{C}: \mathrm{N}$ ratio and carbon contents for maximal conidia production of T. atroviride LU132 were 5:1 and $4.2 \mathrm{~g} / \mathrm{L}$, respectively. The C:N value for maximal $M-G$ and C-P was found as 2:1 in our experimental conditions, which is quite similar to Daryaei et al. [24]. They reported that the greatest inhibition on $R$. solani growth was achieved from conidia produced at high concentration of trehalose. Trehalose accumulation was induced by stress conditions which is required for stress tolerance like dehydration of fungal cells under high temperatures [8, 24, 26, 28]. The highest mycelial growth for T. citrinoviride in this study was found not only when mannitol and trehalose were used but also with glucose, galactose glycerol, mannitol and xylose containing media (Figure 5A).

\section{Effect of different nitrogen sources on growth}

All Trichoderma spp. demonstrated pronounced growth with CSS (Figure 6A and B). T. citrinoviride strains, with the exception of T. citrinoviride EGE-KL-72, exhibited good mycelium growth with yeast extract and soybean flour (Figure 6A). The highest mycelial growth was achieved by T. citrinoviride EGE-K-129 on pepton (Figure 6A).

The results showed that the effect of organic nitrogen sources (corn steep solids > yeast extract $>$ soybean flour) on the growth of T. atroviride and T. citrinoviride species were significantly higher than those observed with inorganic nitrogen sources with the exception of T. citrinoviride EGE-KL-72 (Figure 6A and $\mathrm{B}$ ). The effect of organic nitrogen sources on growth was notably higher than inorganic nitrogen sources.

T. citrinoviride EGE-K-72 showed very weak growth on sodium nitrate and ammonium sulfate and did not grow in the medium containing diammonium hydrogen phosphate. Among the T. citrinoviride strains, T. citrinoviride EGE-K-129 demostrated better growth with inorganic nitrogen sources as compared to the other species (Figure 6A).

T. atroviride strains revealed similar growth patterns on sodium nitrate and ammonium sulfate and their 
A

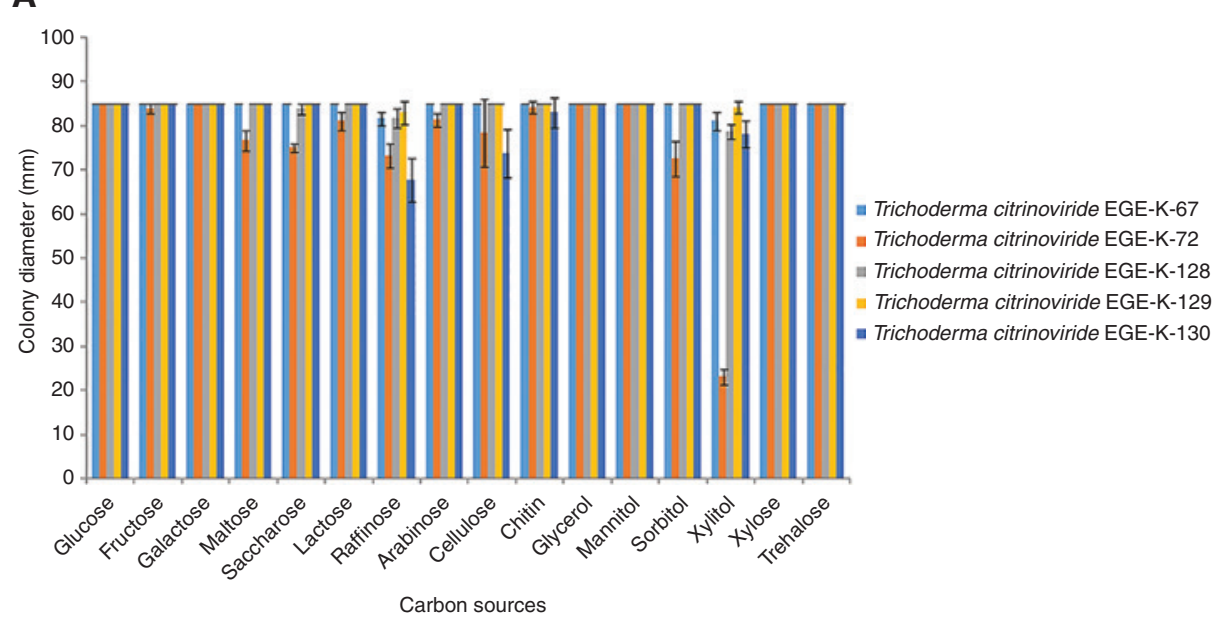

B

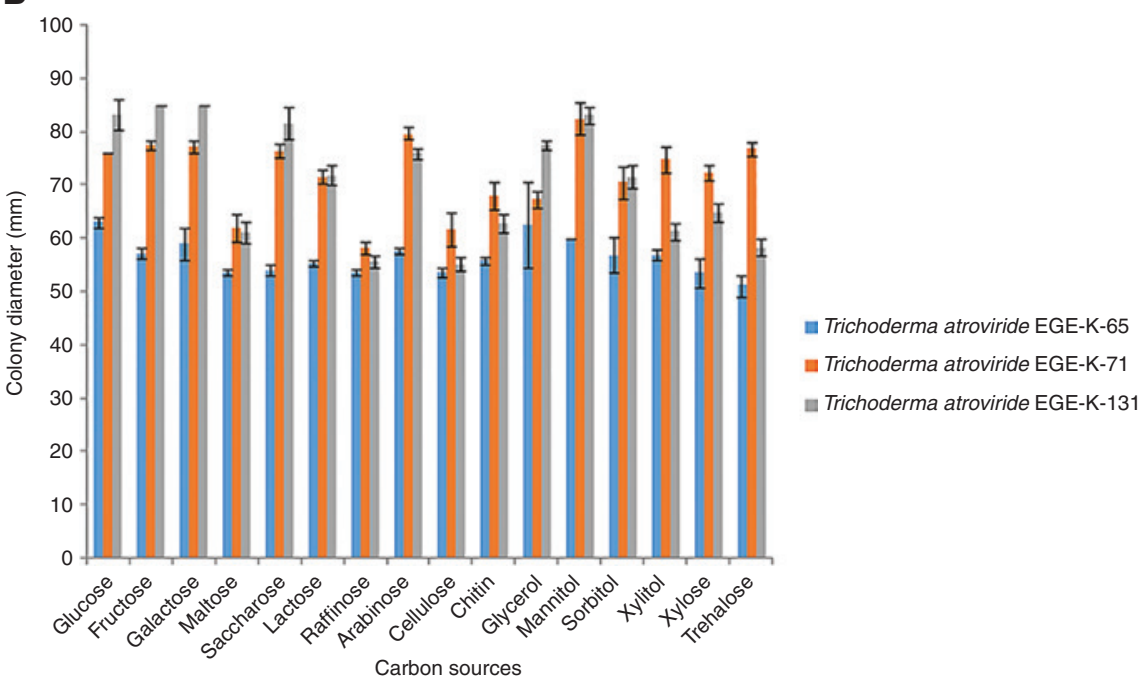

Figure 5: (A) Effect of different carbon sources on mycelia growth profiling of $T$. citrinoviride at $28^{\circ} \mathrm{C}$ for 3 days, (B) Effect of different carbon sources on mycelia growth profiling of $T$. atroviride at $28^{\circ} \mathrm{C}$ for 3 days.

The differences are significant $(\mathrm{p}<0.05)$ between T. citrinoviride and T. atroviride species with different carbon sources.

effect on growth was significantly higher than the one obtained by diammonium hydrogen phosphate. Our results were in agreement with other results obtained by other researchers in which the best growth and sporulation of T. viride and T. harzianum were favored by ammonium forms of nitrogen as compared to nitrite or nitrate forms [35, 39].

As seen on Figure 6A and B, none of the Trichoderma species can grow on urea up to 3 days of cultivation. The minimum mycelial growth was initiated after 4 days of incubation. Towards the end of the incubation period differences between the colony diameters were very high ranging between 10 and $40 \mathrm{~mm}$.

All species produced significant amounts of conidia on all organic nitrogen sources. But, none of the Trichoderma species produce conidia on urea which is in accordance to those reported previously [33]. Trichoderma citrinoviride EGE-K-72 did not produce conidia on inorganic nitrogen sources during 10 days. Exceptionally, $T$. citrinoviride EGE-K-129 produced conidia on diammonium hydrogen phosphate (data not shown).

\section{Conclusion}

The results provided valuable data for achieving highest M-G and C-P of Trichoderma species in terms of their portential as for the preparation of new commercial biological control and biofertilizer formulations under different agro-climatic regions since they exposed growth in a wide temperature range. 
A

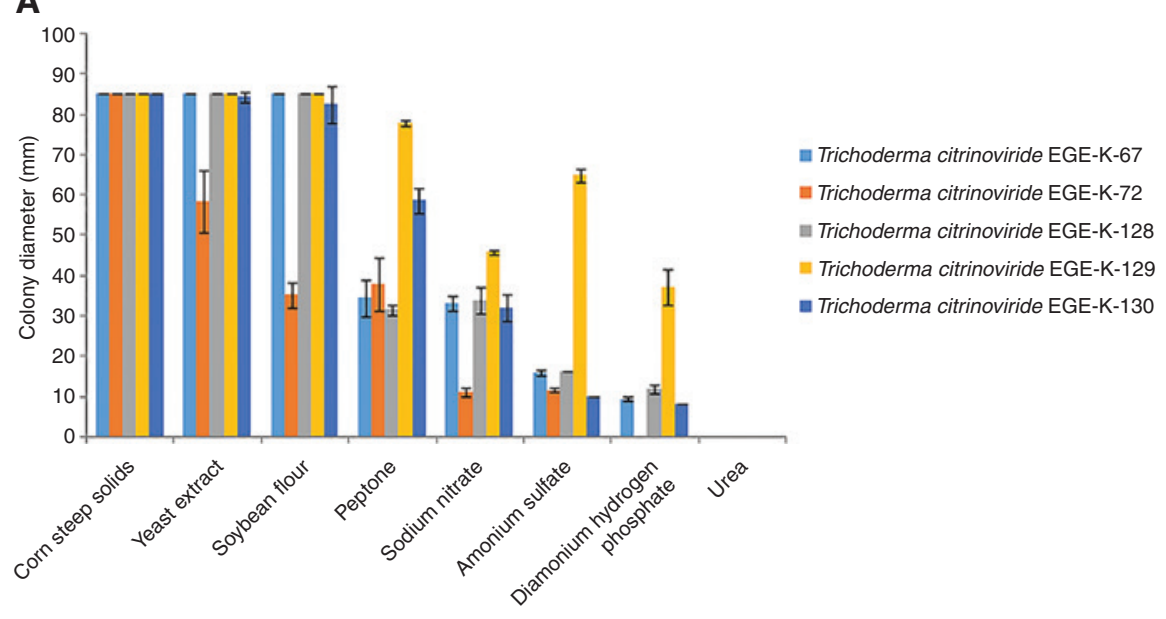

B

Nitrogen sources

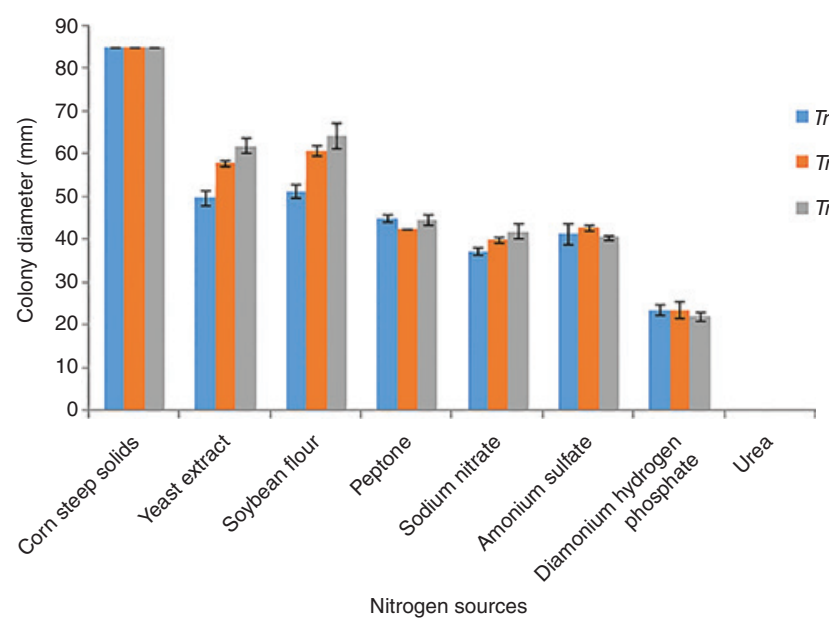

"Trichoderma atroviride EGE-K-65
= Trichoderma atroviride EGE-K-71
= Trichoderma atroviride EGE-K-131

Figure 6: (A) Effect of different nitrogen sources on mycelia growth profiling of $T$. citrinoviride at $28^{\circ} \mathrm{C}$ for 3 days. (B) Effect of different nitrogen sources on mycelia growth profiling of $T$. atroviride at $28^{\circ} \mathrm{C}$ for 3 days.

The differences are significant $(\mathrm{p}<0.05)$ between $T$. citrinoviride and $T$. atroviride species with different nitrogen sources.

In particular, to the best of our knowledge it was the first study concerning the $T$. citrinoviride in respect of BCAs and biofertilizer properties.

According to the results obtained, it was clearly seen that $T$. citrinoviride strains might have potential for use as efficient BCAs and PG-P fungi.

Acknowledgements: The authors wish to thank The Scientific and Technological Reserch Council of Turkey (TUBITAK-MAG) under the grant No 109M551 and Ege University scientific fund under the grant No 13 BIL 024 for financial support of this study.

Conflict of interest statement: The authors declare that there is no conflict of interests regarding the publication of this article.

\section{References}

1. Benítez T, Rincón AM, Limón MC, Codón AC. Biocontrol mechanisms of Trichoderma strains. Int microbiol 2004;7:249-60.

2. Lopes FA, Steindorff AS, Geraldine AM, Brandão RS, Monteiro VN, Júnior ML, et al. Biochemical and metabolic profiles of Trichoderma strains isolated from common bean crops in the Brazilian Cerrado, and potential antagonism against Sclerotinia sclerotiorum. Fungal Biol 2012;116:815-24.

3. Dawidziuk A, Popiel D, Jędryczka M. The influence of Trichoderma species on Leptosphaeria maculans and L. biglobosa growth on agar media and in oilseed rape plants. Integrated Control in IOBC WPRS Bulletin 2013;92:119-26.

4. Błaszczyk L, Siwulski M, Sobieralski K, Lisiecka J, Jędryczka M. Trichoderma spp.-application and prospects for use in organic farming and industry. J Plant Prot Res 2014;54:309-17.

5. Akter Z, Weinmann M, Neumann G, Römheld V. An in-vitro screening method to study the activity potential of biofertilizers 
based on Trichoderma and Bacillus sp. J Plant Nutr 2013;36:1439-52.

6. Vassilev N, Vassileva M, Lopez A, Martos V, Reyes A, Maksimovic I, et al. Unexploited potential of some biotechnological techniques for biofertilizer production and formulation. Appl Microbiol Biotechnol 2015;99:4983-96.

7. Verma M, Brar SK, Tyagi RD, Surampalli RY, Valero JR. Antagonistic fungi, Trichoderma spp.: panoply of biological control. Biochem Eng J 2007;37:1-20.

8. Daryaei A, Jones EE, Ghazalibiglar H, Glare TR, Falloon RE. Culturing conditions affect biological control activity of Trichoderma atroviride against Rhizoctonia solani in ryegrass. J Appl Microbiol 2016a;121:461-72.

9. Daryaei A, Jones EE, Alizadeh H, Glare TR, Falloon RE. Biochemical characteristics of Trichoderma atroviride associated with conidium fitness for biological control. Biocontrol Sci Technol 2016b;26:189-205.

10. Hossain MM, Sultana F, Islam S. Plant growth-promoting fungi (PGPF): phytostimulation and induced systemic resistance. In: Plant-Microbe Interactions in Agro-Ecological Perspectives. Singapore: Springer, 2017:135-91.

11. Kaewchai S, Soytong K. Hyde KD. Mycofungicides and fungal biofertilizers. Fungal Divers 2009;38:25-50.

12. Harman GE, Jin X, Stasz TE, Peruzzotti G, Leopold AC, Taylor AG. Production of conidial biomass of Trichoderma harzianum for biological control. Biol Control 1991;1:23-8.

13. Maral D, Eltem R. Biyokontrol ajanı olarak Trichoderma mikropropagüllerinin sıvı kültür fermentasyonu ile üretim optimizasyonu. Ege Universitesi Fen Bilimleri Enstitüsü Biyomühendislik Anabilim Dalı, 2012, Yüksek Lisans tezi.

14. Chen X, Romaine CP, Tan Q, Schlagnhaufer B, Ospina-Giraldo $M D$, Royse DJ, et al. PCR-based genotyping of epidemic and preepidemic Trichoderma isolates associated with green mold of Agaricus bisporus. Appl Environ Microbiol 1999;65:2674-8.

15. White TJ, Bruns T, Lee SJ, Taylor JW. Amplification and direct sequencing of fungal ribosomal RNA genes for phylogenetics. In: Innis MA, Gelfand DH, Sninsky JJ, White TJ, editors. PCR protocols. A guide to methods and applications. San Diego: Academic Press, 1990:315-22.

16. Bell DK, Wells HD, Markham CR. In vitro antagonism of Trichoderma species against six fungal plant pathogens. Phytopathology 1982;72:379-82.

17. Nikolajeva V, Petrina Z, Vulfa L, Alksne L, Eze D, Grantina L, et al. Growth and antagonism of Trichoderma spp. and conifer pathogen Heterobasidion annosum sl in vitro at different temperatures. Adv Microbiol 2012;2:295-302.

18. Miller GL. Use oi dinitrosalicylic acid reagent tor determination oi reducing sugar. Anal Chem 1959;31:426-8.

19. Chun DS, Kang DK, Kim HK. Isolation and enzyme production of a neutral protease-producing strain, Bacillus sp. DS-1. Korean J Microbiol Biotechnol 2002;30:346-51.

20. Noronha EF, Ulhoa CJ. Purification and characterization of an endo- $\beta$-1, 3-glucanase from Trichoderma harzianum. Can J Microbiol 1996;42:1039-44.

21. Gravel V, Antoun H, Tweddell RJ. Growth stimulation and fruit yield improvement of greenhouse tomato plants by inoculation with Pseudomonas putida or Trichoderma atroviride: possible role of indole acetic acid (IAA). Soil Biol Biochem 2007;39:196877.

22. Murphy J, Riley JP. A modified single solution method for the determination of phosphate in natural waters. Anal Chim Acta 1962;27:31-6.

23. Nautiyal CS. An efficient microbiological growth medium for screening phosphate solubilizing microorganisms. FEMS Microbiol Lett 1999;170:265-70.

24. Daryaei A, Jones EE, Glare TR, Falloon RE. Nutrient amendments affect Trichoderma atroviride conidium production, germination and bioactivity. Biol Control 2016c;93:8-14.

25. Daryaei A, Jones EE, Glare TR, Falloon RE. Biological fitness of Trichoderma atroviride during long-term storage, after production in different culture conditions. Biocontrol Sci Technol 2016d;26:86-103.

26. Daryaei A, Jones EE, Ghazalibiglar H, Glare TR, Falloon RE. Effects of temperature, light and incubation period on production, germination and bioactivity of Trichoderma atroviride. J Appl Microbiol 2016e;120:999-1009.

27. Sargin S, Gezgin Y, Eltem R, Vardar F. Micropropagule production from Trichoderma harzianum EGE-K38 using solid-state fermentation and a comparative study for drying methods. Turk J Biol 2013;37:139-46.

28. Daryaei A, Jones EE, Glare TR, Falloon RE. pH and water activity in culture media affect biological control activity of Trichoderma atroviride against Rhizoctonia solani. Biol Control 2016f;92:2430 .

29. Nieto-Jacobo MF, Steyaert JM, Salazar-Badillo FB, Nguyen DV, Rostás M, Braithwaite M, et al. Environmental growth conditions of Trichoderma spp. affects indole acetic acid derivatives, volatile organic compounds, and plant growth promotion. Frontiers in Plant Scien 2017;8:102.

30. Saravanakumar K, Arasu VS, Kathiresan K. Effect of Trichoderma on soil phosphate solubilization and growth improvement of Avicennia marina. Aquat Bot 2013;104:101-5.

31. Kapri A, Tewari L. Phosphate solubilization potential and phosphatase activity of rhizospheric Trichoderma spp. Braz J Microbiol 2010;41:787-95.

32. Rossi-Rodrigues BC, Brochetto-Braga MR, Tauk-Tornisielo SM, Carmona EC, Arruda VM, Chaud Netto J. Comparative growth of Trichoderma strains in different nutritional sources, using bioscreen c automated system. Braz J Microbiol 2009;40:404-10.

33. Prasad RD, Rangeshwaran R, Anuroop CP, Phanikumar PR. Bioefficacy and shelf life of conidial and chlamydospore formulations of Trichoderma harzianum. Rifai J Biol Control 2002;16:145-8.

34. Bailey BA, Hebbar KP, Lumsden RD, Oneill NR, Lewis JA. Production of Pleospora papaveracea biomass in liquid culture and its infectivity on Opium Poppy (Papaver somniferum). Weed Sci 2004;52:91-7.

35. Rajput AQ, Khanzada MA, Shahzad S. Effect of different organic substrates and carbon and nitrogen sources on growth and shelf life of Trichoderma harzianum. J Agr Sci Tech 2014;16:731-45.

36. Syahiddin, DS. Spore Production of biocontrol agent Trichoderma harzianum: Effect of $\mathrm{C} / \mathrm{N}$ ratio and glucose concentration. J Rekayasa Kimia dan Lingkungan 2007;6:35-40. 
37. Younis M, Khalid M, Rashid A, Ashiq A. Effect of Carbon, nitrogen sources and ascorbic acid on the colony growth and Acervulus production of Pestalotia psydii. Int J Agricult Biol 2004;6:1110-2.

38. Li G, Man HS, Xing ZL, Yong SC. Effects of carbon concentration and carbon to nitrogen ratio on the growth and sporulation of several biocontrol fungi. Mycol Res 2007;111:87-92.
39. Jayaswal RK, Singh R, Lee YS. Influence of physiological and environmental factors on growth and sporulation of an antagonistic strain of Trichoderma viride RSR 7. Mycobiol 2003;31:36-41.

Supplementary Material: The online version of this article offers supplementary material (https://doi.org/10.1515/tjb-2018-0378). 